\section{Zdzisław Pawłowski}

Uniwersytet Mikołaja Kopernika, Toruń

zdziwpaw@umk.p

ORCID: 0000-0002-3042-351X

\section{Biblica}

et

Patristica

Thoruniensia

11 (2018) 2: 159-176

ISSN (print) 1689-5150

ISSN (online) 2450-7059

\title{
Metoda historyczno-krytyczna i analiza narracyjna w perspektywie założeń hermeneutycznych
}

\section{The Historical-Critical Method and the Narrative Analysis in Hermeneutical Perspective}

\begin{abstract}
Streszczenie. Współczesna hermeneutyka filozoficzna jest niezbędna dla egzegetów, dostarcza bowiem rozwiązań, które mogą pomóc w przezwyciężeniu kryzysu dzisiejszej interpretacji biblijnej. Rzuca ona światło na dwojaki kontekst społeczny, w którym lektura Biblii się odbywa. Uniwersytet zmusza egzegezę do uzasadnienia i uprawomocnienia procedur interpretacyjnych, broniąc ją tym samym przed arbitralną dowolnością odczytań tekstów biblijnych ze strony zwykłych czytelników. Z kolei Kościół przypomina egzegezie naukowej niezbywalną dla niego prawdę, że tylko w stopniu, w jakim otwiera się na problematykę aktualizacji orędzia biblijnego w życiu czytelników, może ona na nowo oddać się na służbę jego misji w świecie. A zatem egzegeza naukowa musi poddać metody naukowe (zachowując ich autonomię) służbie hermeneutyki wiary, wsłuchując się w potrzeby wspólnoty wierzących i wchodząc z nimi w twórczy dialog i interakcję.
\end{abstract}

\begin{abstract}
The Contemporary philosophical hermeneutics is essential for the exegetes. It provides the ways to resolve some of the problems of today biblical interpretation. The recent hermeneutical debates have revealed the kinds of implicit positivism that characterizes biblical research in formal detachment from faith and theology. Its causes the obsessive preoccupation with methods. There is urgent need of a new model of biblical hermeneutics aiming at the renewal of interaction between Scripture and theology. It should not so much be concerned with amassing 'theoretical' knowledge, as rather enhance a sort of practical knowledge and truth that shapes our praxis by the way of appropriation of a living Word of God.
\end{abstract}

Słowa kluczowe: hermeneutyka; metoda historyczno-krytyczna; analiza narracyjna; rozumienie; wyjaśnienie; zastosowanie.

Keywords: hermeneutics; historical-critical method; narrative analysis; understanding; explanation; application. 
Termeneutyka jako zbiór zasad i metod interpretacji tekstów biblijnych 1 stanowi podstawowe wyposażenie naukowego warsztatu biblistów. Praktyczne zastosowanie określonej metodologii nie zawsze jednak idzie w parze ze świadomością jej założeń i ograniczeń. Do tego potrzebna jest bowiem znajomość współczesnej hermeneutyki filozoficznej. Ta zaś odsłania przesłanki, ukryte w złożonym procesie interpretacji każdego tekstu. Paul Ricoeur, jeden z jej twórców, definiuje szeroki zestaw problemów, towarzyszących interpretacji:

[U]traciliśmy już naiwność metodologiczną i bynajmniej nie jest rzeczą samą w sobie oczywistą, że rozumienie jakiegoś tekstu polega na dociekaniu autorskich intencji [...]. Nie ma też co wierzyć tak samo naiwnie, że rozumienie jakiegoś tekstu polega na docieraniu do jego źródeł, do jego przed-redakcyjnego stanu, do otaczającej go rzeczywistości; między tymi źródłami a nami stają liczni pośrednicy, spośród których niejeden zasłania nam tylko widok. Co to jest mowa? Co to jest język? Co to jest akt słowny? Co to jest tekst? Co to jest pismo? Co to jest sens? Wszystkie te wyrazy stały się problematyczne i wskazują na ustawionych między czytelnikiem i autorem pośredników, z których każdy daje sposobność do nowej dyskusji ${ }^{1}$.

W zwielokrotnionym stopniu powyższe pytania odnoszą się do egzegezy biblijnej, która od dłuższego czasu znajduje się w permanentnym kryzysie. Objawia się on głównie w coraz bardziej pogłębiającej się przepaści między naukową interpretacją Biblii, uprawianą w akademickiej przestrzeni wydziałów teologicznych, a przepowiadaniem i czytaniem Pisma, praktykowanym we wspólnotach wierzących, w kościele. Świat naukowej egzegezy i świat zwykłych czytelników Biblii (niekoniecznie tylko wierzących) to dwa nieprzenikające się i odgrodzone od siebie wysokim murem terytoria. Obydwa posługują się odmienną koncepcją tekstu biblijnego i różnią się znacząco sposobami i celami jego interpretacji ${ }^{2}$. Pierwszy, zanurzając się w przeszłość analizowanych tekstów (bliżej mu do archeologii i historii, dokumentującej fakty przeszłości niż do sztuki interpretacji), z metodologiczną premedytacją bierze w nawias

1 P. Ricoeur, Egzystencja i hermeneutyka. Rozprawy o metodzie, s. 327n.

2 K.D. Sakenfeld (Whose Text Is It?, s. 9n.) wyróżnia pięć linii demarkacyjnych, oddzielających różne kategorie czytelników, posługujących się odmiennymi koncepcjami tekstu biblijnego: metody akademickie, religijna/świecka interpretacja, żydowscy i chrześcijańscy/ /inni czytelnicy, społeczno-kulturowe tradycje łącznie z kulturowymi, etnicznymi, płciowymi, ekonomicznymi i politycznymi wymiarami, oraz 'zwykli'/'specjalistyczni' czytelnicy. Podstawą odrębności każdej z nich są jednak kryteria socjologiczne, a nie hermeneutyczne, te bowiem mają swoje źródło w rozumieniu jako istocie problemu hermeneutycznego. Por. także Z. Pawłowski, Wiara i metoda w interpretacji Biblii. Przekaz wiary czy przekaz wiedzy: biblijna interpretacja na rozdrożu, s. 9-28. 
potrzeby współczesnego czytelnika jako wykraczające poza sferę naukowych dociekań. Dzisiejszy czytelnik z kolei, pozostając pod silnym wpływem aktualnie dominującej kultury, traci w ogóle zainteresowanie Biblią, a jeśli ją czyta, to wyłącznie przez pryzmat osobistych oczekiwań i poglądów, nie sięgając bynajmniej do uczonych komentarzy i opracowań zawodowych biblistów. Naukowa interpretacja Biblii, ograniczając się często do analizy formalnych aspektów tekstu, nie wykazuje większego zainteresowania sprawą, o której tekst mówi, przez co nie stanowi już punktu wyjścia dla refleksji w ramach teologii systematycznej i praktycznej, kroczących własną drogą, niezależną od badań biblijnych, ani też dla duchowości zwykłych wierzących, dla których Biblia jest zbiorem opowieści z zamierzchłych czasów, nie wspominając odniesień do aktualnych problemów społecznych, których rozwiązania poszukuje się przede wszystkim w najnowszych osiągnięciach nauki. Jeśli Biblia ma mieć jeszcze coś do powiedzenia dzisiaj i w przyszłości i nie znaleźć się w zbiorze nieaktualnych, starożytnych dokumentów (egipskich, asyryjskich, babilońskich), to istnieje potrzeba wypracowania takiego modelu hermeneutyki biblijnej, która nie tylko przywróci jej aktualność, lecz także umożliwi spotkanie różnych opcji czytelniczych na jednej wspólnej płaszczyźnie, pozwalając na konstruktywny i twórczy dialog między nimi.

\section{Zarys problemu hermeneutycznego}

Współczesna hermeneutyka filozoficzna jest projektem stosunkowo nowym, ale w ostatnich kilkudziesięciu latach rozwija się niezwykle dynamicznie, obejmując szeroki wachlarz różnorodnych dziedzin ${ }^{3}$. Do końca XIX w. istniały tzw. hermeneutyki szczegółowe, zawierające konkretne reguły wykładni tekstów, mające zastosowanie w interpretacji klasycznych dzieł grecko-rzymskiej literatury i filozofii, prawa i Biblii. Wszystkie te trzy obszary aktywności interpretacyjnej należały do jednego wspólnego świata chrześcijańskiej myśli i praktyki, wyjaśniając siebie nawzajem i tworząc na ich podstawie zasady postępowania. Biblia w szczególności stanowiła jedynie część długiej i bogatej tradycji dogmatycznej i duchowej, wewnątrz której jej sens pozostawał jasny i zrozumiały, co gwarantował autorytet nauczającego Kościoła, i co sprowadzało ją do zbioru cytatów, potwierdzających powszechnie akceptowaną doktrynę. Podobny status posiadała natura, którą przedstawiano jako rodzaj księgi napisanej palcem

3 Krótką historię powstania i rozwoju hermeneutyki filozoficznej można znaleźć w: Z. Pawłowski, Opowiadanie, Bóg i początek. Teologia narracyjna Rdz 1-3, s. 25-55. 
Boga, objawiającą Jego niewidzialną mądrość ${ }^{4}$ Średniowieczna hermeneutyka obowiązująca przez wiele stuleci pomijała w zasadzie historyczny charakter tekstów biblijnych, traktując je jako jednorodne dzieło, będące zbiorem odwiecznych prawd, aktualnych w każdym czasie i w każdym miejscu ${ }^{5}$. Pismo, jego autorzy i czytelnicy podzielali ten sam pogląd na świat. Między nimi zachodziła relacja podobieństwa i korespondencji, wszystko w nim było oczywiste i zrozumiałe (to, co niezrozumiałe należało do rzadkości), a komentarze do Biblii, zgodnie z przekonaniem Tomasza z Akwinu, umożliwiały czytającym uczestniczenie w tym, co stanowiło przedmiot jej wykładni ${ }^{6}$. Z tego względu egzegeza biblijna Tomasza, jak i w ogóle średniowiecznych komentatorów ${ }^{7}$, wydaje się nie przystawać do dzisiejszej sytuacji hermeneutycznej, naznaczonej świadomością historycznego dystansu dzielącego nas od interpretowanych tekstów.

A pojawiła się ona w momencie rozkwitu historii jako nauki i wypracowania metod krytycznego badania przeszłości, dla którego podstawowym problemem była odpowiedź na pytanie „jak było naprawdę" (L. von Ranke). Pytanie to postawiono również historii przedstawionej w Biblii. Wraz z przełomowymi pracami Wellhausena, dotyczącymi Pięcioksięgu i jego hipotezą dokumentarną, poszczególne księgi biblijne i ich mniejsze fragmenty zaczęły powracać do czasu swego powstania, oddalając się czasowo i przestrzennie od swoich czytelników, żyjących w erze nowożytnej, w świecie zachodnim. Bezpośrednim skutkiem tych procesów było pozbawienie tekstów biblijnych statusu odwiecznych i niezmiennych prawd i umieszczenie opisywanych przez nie zdarzeń w konkretnym usytuowaniu historycznym i geograficznym. W ten sposób rozpoczął się proces historyzacji i kontekstualizacji Biblii. Szybko też się okazało, że w przeciwieństwie do klasycznych dzieł literatury grecko-rzymskiej, z których każde posiadało względną spójność i jednego znanego autora, teksty biblijne mają na tyle złożony charakter, że trzeba je przypisać różnym, najczęściej anonimowym autorom i opatrzyć różnymi datami powstania ${ }^{8}$. Biblia zatem jako

4 Por. P. Harrison, The Bible, Protestantism, and the Rise of Natural Science. Analizuje on zmiany zachodzące w sposobach i metodach interpretacji Biblii, które stały się istotnym faktorem w rozwoju nauk przyrodniczych.

5 P. Harrison, The Bible, s. $121 \mathrm{n}$.

6 Por. W. Iser, The Range of Interpretation, s. 45.

7 Renesans tej egzegezy, dokonujący się najczęściej poza kręgiem biblistów, świadczy o powrocie do przed-krytycznego etapu w historii interpretacji. Bibliści, owszem, powołują się na egzegezę średniowieczną, ale czynią to w ramach metody Wirkungsgeschichte, krytycznie analizując historię oddziaływania tekstu biblijnego i jego późniejszą recepcję.

8 Por. R.N. Whybray, The Making of the Pentateuch. A Methodological Study, s. 17-31. 
część tradycji, oczywista dotąd w swej wykładni, stała się tekstem obcym i niezrozumiałym, należącym do odległej przeszłości, z odmienną kulturą i obrazem świata.

Ten stan rzeczy doskonale zdiagnozował Friedrich Schleiermacher, ojciec współczesnej hermeneutyki filozoficznej. Wychodząc od problemów związanych z interpretacją Pisma, stwierdził, że jeśli wcześniej niezrozumienie jakiegoś tekstu było odstępstwem od reguły, to teraz stało się normą. Nic w Biblii nie było już oczywiste, stąd zrozumienie wyłoniło się jako podstawowy i główny cel interpretacji ${ }^{9}$. Tym samym, hermeneutyka ze zbioru szczegółowych reguł wykładni konkretnego tekstu przekształciła się w teorię rozumienia w wymiarze językowej komunikacji, a więc nabrała charakteru uniwersalnego w odniesieniu do wszystkich tekstów oraz wszystkich innych form przekazu i ekspresji ${ }^{10}$.

Jako działanie komunikacyjne w służbie przezwyciężenia dystansu, jaki dzieli od tego, co obce (czasowo - należące do innej epoki i przestrzennie - rozgrywające się w odmiennym obszarze geograficznym) rozumienie ciągle pozostawało tylko problemem teoriopoznawczym (Schleiermacher, Dilthey), w ramach którego starano się udoskonalić metody interpretacji, aby je osiągnąć. Głębszy wymiar rozumienia wprowadził M. Heidegger, który w Sein und Zeit ${ }^{11}$ starał się odsłonić jego status ontologiczny, pytając o sposób bycia, którego istnienie urzeczywistnia się właśnie w rozumieniu ${ }^{12}$. Zakwestionował podział istniejący w epistemologii na podmiot i przedmiot ${ }^{13}$. W procesie poznania podmiot i przedmiot oddziałują na siebie tak, że tożsamość poznającego, to kim jest, warunkuje to, czego się dowie o przedmiocie, a z kolei przedmiot posiada swoistą władzę nad poznającym, określając sposoby jego ujmowania ${ }^{14}$. Ta wzajemność oddziaływania na siebie podmiotu i przedmiotu w procesie poznania wydaje się poruszać po błędnym kole, które sprawia, że interpretacja sytuuje się poza możliwościami ścisłej wiedzy, charakteryzującej nauki przyrodnicze. Jednak koło w rozumieniu nie jest wcale błędnym, gdyż należy do struktury

9 W. Iser, The Range of Interpretation, s. 41.

10 Zob. M. Forster, "Friedrich Daniel Ernst Schleiermacher”, The Stanford Encyclopedia of Philosophy (Fall 2017 Edition), Edward N. Zalta (ed.), URL $=<$ https://plato.stanford.edu/ archives/fall2017/entries/schleiermacher/> (dostęp: 02.05.2018). Przejście od hermeneutyk szczegółowych do hermeneutyki ogólnej na płaszczyźnie teorii rozumienia omawia Z. Pawłowski, Opowiadanie, Bóg i początek, s. 26-29.

11 Polski przekład: Bycie i czas, Warszawa 1994.

12 Por. Z. Pawłowski, Opowiadanie, Bóg i początek, s. 33-35.

13 W egzegezie tekst biblijny jest analizowanym za pomocą metody przedmiotem, mającym w zasadzie niewiele wspólnego z podmiotowością egzegety.

14 W praktyce egzegetycznej widoczna jest jedynie władza interpretatora nad badanym tekstem, podczas gdy oddziaływanie tekstu na egzegetę pozostaje niesymetrycznie małe. 
sensu, ten zaś coraz bardziej pogłębia się i poszerza, poruszając się po spirali wzajemnego oddziaływania poznania i jestestwa.

Przejmując od Heideggera ontologiczny wymiar hermeneutyki, H.-G. Gadamer podjął problematykę rozumienia, rozwijając ją w kierunku fundamentalnej teorii wiedzy, która jako założenie jest obecna we wszelkich metodycznych próbach poznawczych ${ }^{15}$. Według niego każdy tekst należy do całości tradycji, która określa także pozycję interpretatora ${ }^{16}$, sprawia też, że jego sens zawsze przewyższa intencję autorską, stanowiąc w stosunku do niej pewną nadwyżkę. Rozumienie zatem nigdy nie jest procesem odtwarzającym, lecz ma zawsze twórczy charakter, wynikający $\mathrm{z}$ hermeneutycznej produktywności dystansu czasowego. Dopiero bowiem czasowe oddalenie umożliwia wyłonienie się prawdziwego sensu danej rzeczy. Sprawia ono, że wyczerpanie sensu w jakimś dziele artystycznym nigdy nie zostaje zakończone, lecz jest procesem nieskończonym ${ }^{17}$.

Według Gadamera, dystans czasowy umożliwia oddzielenie prawdziwych projekcji sensu, przy których rozumiemy, od fałszywych, przy których błędnie rozumiemy, tworząc wyszkoloną w hermeneutyce świadomość historyczną ${ }^{18}$. Jest ona przede wszystkim świadomością hermeneutycznej sytuacji, w jakiej się znajdujemy ze względu na przekaz tradycji, który mamy zrozumieć. Chcąc zrozumieć jakiś tekst, zawsze umieszczamy siebie w pewnej sytuacji, ta zaś z definicji ogranicza możliwości widzenia, którego granice wyznacza horyzont. Wykreślają go pytania, jakie stawia przed nami ów przekaz tradycji. Dochodzimy do nich jednak nie przez zastosowanie myślenia historycznego, które zwalnia tekst z powinności mówienia prawdy. Gadamer podkreśla, że przenosząc się w sytuację historyczną tekstu i starając się odtworzyć jego horyzont historyczny, może nam się wydawać, że rozumiemy. Tymczasem, ograniczając się do wyjaśnienia faktów dotyczących powstania tekstu i jego znaczenia w przypisanej mu sytuacji historycznej, rezygnujemy ze znajdowania w nim zrozumiałej i zobowiązującej nas prawdy ${ }^{19}$. Dlatego proces rozumienia tekstu odbywa się według

15 Zob. Prawda i metoda. Zarys hermeneutyki filozoficznej.

16 W przekonaniu wielu egzegetów, metoda gwarantuje neutralność i obiektywizm interpretacji, wyłączając go w jakiś cudowny sposób spod wpływu tradycji i własnego kulturowego kontekstu. Gadamer demaskuje naiwność tzw. obiektywizmu historycznego, który ufając metodyce swego postępowania zapomina o własnej dziejowości (por. Prawda i metoda, s. 284).

17 H.-G. Gadamer, Prawda i metoda, s. 282nn.

18 Por. ibidem, zob. także Z. Pawłowski, Opowiadanie, Bóg i początek, s. 38.

19 Gadamer zaznacza także, że „metoda historyczna przyjmuje milcząco założenie, że trwałe znaczenie czegoś daje się obiektywnie poznać dopiero wtedy, gdy należy do jakiegoś 
niego w sytuacji hermeneutycznej (z której nie można wyjść ani jej opuścić), w której spotykają się zawsze dwa horyzonty: historyczny tekstu i współczesny czytelnika $^{20}$. W stapianiu horyzontów tekstu i interpretatora ujawnia się trzecia faza problemu hermeneutycznego - zastosowanie, którego w opinii Gadamera nie można wyeliminować z obszaru hermeneutyki. W ukształtowanej przez świadomość historyczną naukowej teorii poznania dominującej w ostatnich dwóch stuleciach, zastosowanie znaczenia tekstu do obecnej sytuacji czytelnika traktowano jako poważne naruszenie obiektywności interpretacji. Gadamer jednak stanowczo potwierdza, że bez zastosowania nie ma w ogóle rozumienia, i dotyczy to nie tylko tekstów biblijnych czy sądowych, lecz w ogóle wszelkich działań komunikacyjnych, w których pojawia się problem rozumienia. Obok więc intellectio (rozumienia) i explicatio (wyjaśnienia) akt interpretacji, wynikający z sytuacji hermeneutycznej musi ze swej natury obejmować również applicatio (zastosowanie).

Gadamer nie poprzestaje jednak na włączeniu zastosowania w doświadczenie sensu. W ostatniej części Prawy $i$ metody omawia językowy charakter procesu rozumienia. Stapianie się horyzontów w wymiarze działania komunikacyjnego odbywa się bowiem zawsze na płaszczyźnie języka. To język sprawia, że rozumienie nie polega na wstawianiu się w położenie innego i doznawaniu jego przeżyć, lecz przyjmuje formę porozumienia co do danej sprawy ${ }^{21}$.

Miejsce, w którym Gadamer zwieńcza swoje rozważania hermeneutyczne, jest punktem wyjścia dla Paula Ricoeura w jego projekcie teorii interpretacji. W jej centrum nie jest już język, lecz tekst, który przekształca ją w hermeneutykę tekstualną ${ }^{22}$. Tym samym powraca on do metody, której ograniczenia i niewystarczalność w dochodzeniu do prawdy akcentował tak mocno Gadamer. Przeciwnie, Ricoeur usiłuje włączyć metodę w proces interpretacji tekstu, wyznaczając jej właściwą funkcję w strukturze łuku hermeneutycznego. Wykorzystując przemyślenia Kanta dotyczące sądów analitycznych i syntetycznych, ujmuje on problem hermeneutyczny jako dialektykę rozumienia i wyjaśnienia, znajdującą swój wyraz w dialogu, w którym ktoś wyjaśnia coś drugiemu, aby

zamkniętego kontekstu. Innymi słowy: gdy jest na tyle martwe, by budzić już tylko historyczne zainteresowanie." (Prawda i metoda, s. 283).

20 Por. Z. Pawłowski, Opowiadanie, Bóg i początek, s. 39. Nie jest to proces dowolnie dodany w formie aktualizacji, pozbawionej rygorów naukowości, do wcześniejszych etapów interpretacji dokonujących się za pomocą wybranej metody naukowej, lecz działanie obejmujące całość aktu interpretacji, od początku do końca.

21 Por. H.-G. Gadamer, Prawda i metoda, s. 353-442.

22 Jej najważniejsze elementy w skrócie przedstawia Z. Pawłowski, Opowiadanie, Bóg i początek, s. 40-55. 
zrozumiał. Wyjaśnianie jest procedurą analityczną, wydobywającą z cząstkowych ujęć szereg sądów i znaczeń. Z kolei rozumienie jest procedurą syntetyczną, w trakcie której łańcuch cząstkowych znaczeń usiłuje się połączyć w jedną sensowną całość ${ }^{23}$. Tym samym zastosowanie w ujęciu Ricoeura jest pouczo$n a$ przez wyjaśnienie nową formą rozumienia. Dlatego zamiast zastosowania znaczenia tekstu do samego siebie, jak u Gadamera, woli on mówić o przyswojeniu jego sensu przez czytelnika. To zaś zakłada, że w akcie interpretacji znaczenie tekstu jest czymś ukrytym, co należy przełożyć w rozumienie ${ }^{24}$. Na początku tego procesu rozumienie stanowi raczej naiwne, obciążone własnymi domysłami, uchwycenie sensu tekstu w jego całości. Na końcu, w momencie przyswojenia, przekształca się $\mathrm{w}$ głębsze rozumienie, oparte na procedurach wyjaśniających. W ten sposób wyjaśnienie staje się częścią procesu rozumienia, pośrednicząc między dwiema jego fazami ${ }^{25}$.

Z perspektywy przyswojenia Ricoeur na nowo definiuje gadamerowskie stapianie się horyzontów. W jego przekonaniu, sens tekstu nie kryje się już za tekstem, lecz stoi przed nim. Rozumienie, będące motorem interpretacji kieruje się nie na sytuację, w której tekst powstał, lecz na jego odniesienie do świata przezeń odsłoniętego. W trakcie interpretacji odbywa się zatem stapianie się horyzontów świata tekstu i świata czytelnika. Przyswojenie bowiem nie jest aktem przemocy czytelnika wobec tekstu, lecz zakłada proces przemiany podmiotu, który dobrowolnie wystawia się na jego działanie, w taki sposób, że obydwa światy, tekstu i czytelnika, zaczynają przenikać się wzajemnie ${ }^{26}$.

Wyjaśnienie zatem jako odrębny etap interpretacji w łuku hermeneutycznym, nie jest samoistną i samowystarczalną procedurą interpretacyjną, której celem jest zdobycie jak największej ilości informacji o tekście (często zbędnych i w ogóle nieprzydatnych). Jego celem, realizowanym przez zastosowanie odpowiedniej metody lub zestawu metod, jest zawsze służyć rozumieniu, działającym w stosunku do niego jak brzytwa Ockhama ${ }^{27}$. Alonso Schökel w swoich wykładach z hermeneutyki podkreślał, że ktoś może znać wszystkie dane na temat tekstu i ciągle go nie rozumieć ${ }^{28}$. To, co oferuje współczesna egzegeza,

\footnotetext{
23 Por. P. Ricoeur, Język, tekst, interpretacja. Wybór pism, s. 157.

24 Por. W. Iser, The Range of Interpretation, s. 69.

25 Por. P. Ricoeur, Język, tekst, interpretacja, s. 160n.

26 Por. Z. Pawłowski, Opowiadanie, Bóg i początek, s. 53-55.

27 Ockham podkreśla, że nie wolno przyjąć niczego bez uzasadnienia. Musi ono być oczywiste albo znane na mocy doświadczenia, albo zapewnione przez autorytet Pisma Świętego. Chodziło mu przede wszystkim o dostarczenie narzędzia, pozwalającego na krytykę nadmiernie rozbudowanych, spekulatywnych systemów średniowiecznej scholastyki.

28 L.A. Schökel, A Manual of Hermeneutics, s. 170.
} 
to ciągle powiększający się zbiór informacji natury filologicznej, historycznej i literackiej. Tworzy on ogromną, częściowo wirtualną encyklopedię wiedzy biblijnej, niemającą wiele wspólnego z aktem interpretacji, w którym zawsze chodzi o aktualną wykładnię tekstu.

\section{Założenia metody historyczno-krytycznej w świetle hermeneutyki}

Na metodę historyczno-krytyczną składa się kilka procedur, które mają jeden wspólny mianownik. Jest nią powszechnie akceptowana zgoda na to, że teksty biblijne należy interpretować $\mathrm{w}$ ich historycznym usytuowaniu, w świetle literackich i kulturowych konwencji czasów ich powstania. Pozornie z tym twierdzeniem trudno się nie zgodzić. Przyjmuje się również, że znaczenie tekstu da się ustalić w sposób obiektywny przez zastosowanie właściwych metod. Choć akceptuje się prowizoryczność rekonstrukcji sensu, zamierzonego przez starożytnego autora, to nie kwestionuje się jednak metodologii doń prowadzącej $^{29}$. Co więcej, zakłada się także, że tekst może przyjmować nowe znaczenia w zmieniających się okolicznościach historycznych, co postulowane jest przez kolejne redakcje, którym jest poddawany.

Problematyczność powyższych zasad wynika z tego, że bierze się pod uwagę wyłącznie historyczny horyzont tekstu, z całkowitym pominięciem horyzontu współczesnego interpretatora, jakby jego własny kontekst historyczny i kulturowy nie miał żadnego wpływu na sposób odczytywania tekstu, a co zgodnie z ustaleniami Gadamera, stanowi istotę aktu interpretacji. Egzegeta traktuje metodę jako rodzaj wirtualnego pojazdu, przenoszącego go w czasy powstawania tekstu. Przesłanka ta pochodzi z przejęcia pozytywistycznej koncepcji historii, chcącej upodobnić się do nauk empirycznych, w których metoda stanowi jedyny sposób wyjaśniania zjawisk fizycznych. Zrozumieć zjawiska fizyczne oznacza tutaj wyjaśnić działające w nich procesy. Wyjaśnienie i zrozumienie nie są tutaj wprost działaniami komunikacyjnymi, zachodzącymi między podmiotem poznającym a badanym przedmiotem. W przypadku tekstów artystycznych w humanistyce, szczególnie w Biblii, wyjaśnienie jest podporządkowane rozumieniu, które ze swej istoty zamierza komunikację, dialog między dwoma stronami aktu interpretacji. Po co interpretuję? Żeby zrozumieć znaczenie tekstu, a nie wyjaśnić zjawiska zachodzące podczas jego powstawania lub ustalić wydarzenia historyczne, do których się odnosi. Sprowadzony do wyjaśnienia proces interpretacji odbywa się więc w granicach wyznaczonych przez metodę

29 Por. J. Collins, The Bible after Babel. Historical Criticism in a Postmodern Age, s. 4. 
jako procedurę analityczną, gwarantującą osiągnięcie wyników na wzór obiektywności twierdzeń empirycznych. Wyjście poza nie jest wprowadzeniem nienaukowej subiektywności. A zatem wszelkie próby tzw. aktualizacji znaczenia tekstu przez współczesnego czytelnika, wykraczają poza sferę naukowej aktywności, w której nie ma dla nich miejsca ${ }^{30}$. Tymczasem pytanie historyka nie jest wcale neutralnym pytaniem, lecz pytaniem uzbrojonym w ideę możliwych źródeł i badawczych procedur, wypracowanych w oparciu o wcześniej przyjętą teorię. Dlatego twierdzenie Papieskiej Komisji Biblijnej w dokumencie z 1993 r., że metoda historyczno-krytyczna nie zawiera sama w sobie żadnego a priori ${ }^{31}$, może wprowadzać w błąd. Nie ma bowiem metody bez założeń. Przyznanie na przykład większej wiarygodności odkryciom archeologicznym, które same wymagają interpretacji niż dokumentom pisanym, jest decyzją podjętą na podstawie wcześniejszych przesłanek hermeneutycznych i wpływa rozstrzygająco na sposoby przedstawiania historii biblijnej.

Przekonanie, że egzegeza historyczno-krytyczna pozwala ustalić obiektywny sens tekstu, umieszczając autorów biblijnych w ich historycznym, społeczno-politycznym, kulturowym i religijnym kontekście, zrodziło się w okresie Oświecenia jako próba chrześcijańskiej odpowiedzi na wyzwania płynące z nowego paradygmatu historii, który postulował wytworzenie procedur badawczych umożliwiających ustalenie faktów historycznych z pewnością charakteryzującą twierdzenia, dotyczące zjawisk naturalnych ${ }^{32}$. Dokonana wtedy zamiana tekstu biblijnego na historię w nim opowiedzianą spowodowała istotne przesunięcie na płaszczyźnie hermeneutycznej. Odtąd, fundamentem wiary chrześcijańskiej stała się prawda historyczna (oczywiście, zdefiniowana przez egzegetów), odróżniając ją od religii opartej na mitach. Jakiekolwiek podważanie prawdziwości konkretnych wydarzeń historycznych, powoduje zagrożenie wiary i zakwestionowanie autorytetu Pisma, nierozerwalnie związanego $\mathrm{z}$ wiarygodnością przedstawionej w nim historii ${ }^{33}$. Stąd problemy dzisiejszych czytelników Biblii z akceptacją biblijnych opowieści, mających luźne związki $\mathrm{z}$ historią rekonstruowaną przez historyków lub pozbawionych odniesień do konkretnych faktów historycznych.

30 Por. Ks. M. Kowalski, Retoryka i socjoretoryka w lekturze tekstów Nowego Testamentu. Cz. 2: Socjoretoryka - projekt holistycznej lektury tekstu, s. 139.

31 Por. R. Rubinkiewicz (przekł. i red.), Interpretacja Biblii w Kościele. Dokument Papieskiej Komisji Biblijnej z komentarzem biblistów polskich, s. 32.

32 Por. J.J. Collins, The Bible after Babel, s. 4.

33 Por. K. Spark, The Prophetic Speeches in Chronicles. Speculation, Revelations, and Ancient Historiography, s. 235. 
Zgodnie z tymi założeniami, najważniejszym i często jedynym zadaniem egzegety posługującego się metodą historyczno-krytyczną jest ustalenie znaczenia tekstu $\mathrm{w}$ jego kontekście historycznym, z uwzględnieniem sytuacji pierwszych adresatów, którą próbuje odtworzyć najczęściej na podstawie źródeł pozabiblijnych. Kiedy dochodzi do pytania, co tekst znaczy dzisiaj, odmawia odpowiedzi, przeświadczony, że nie wchodzi ono w zakres jego naukowej kompetencji, lecz stanowi raczej problem subiektywnej lektury - duchowej lub teologicznej, która dzięki znaczeniu ustalonemu przez niego może go aktualizować w zależności od swoich potrzeb i oczekiwań. Egzegeta zachowuje się wobec tekstu tak jak fizyk w stosunku do przyrody. Lecz tekst nie jest zjawiskiem fizycznym, lecz dziełem jakiegoś podmiotu, które chce coś zakomunikować innemu podmiotowi.

Właśnie aktualizacja znaczenia tekstu $\mathrm{w}$ formie normatywnej interpretacji teologicznej jest tu najbardziej problematyczna. Cytowany dokument Papieskiej Komisji Biblijnej zbyt pochopnie zakłada kompatybilność egzegezy historyczno-krytycznej z interpretacją teologiczną, odwołując się milcząco do tzw. zasady analogii. Twierdzi ona, że istnieje daleko posunięte podobieństwo i korespondencja między sytuacjami w przeszłości a współczesnymi. Ponieważ natura ludzka się nie zmienia, jej znajomość pozwala wnioskować z dużą dozą prawdopodobieństwa o sposobach postępowania ludzi w starożytności i przerzucić pomost do dzisiejszych zachowań ${ }^{34}$. Podejście diachroniczne do tekstu sprawia jednak, że zasada ta w praktyce egzegetycznej nie ma zastosowania, bo jeśli nawet przyjmie się ostatnią redakcję jako finalną postać tekstu, to jego wykładnia i tak ma charakter prowizoryczny ze względu na niejednoznaczność i hipotetyczność wcześniejszych etapów, prowadzących różnych egzegetów do odmiennych znaczeń. W konsekwencji oznacza to śmierć Pisma jako słowa Bożego i zdegradowanie go do zbioru mało wiarygodnych dokumentów historycznych, obciążonych ideologicznym nastawieniem swoich autorów.

Zastosowanie w egzegezie różnych metod, wypracowanych w ramach odmiennych hermeneutyk (zorientowanych na historię, tekst lub czytelnika), sprawia, że wbrew rozpowszechnionej opinii, ich połączenie nie jest wcale oczywiste, lecz rodzi nieusuwalne napięcia, z których egzegeta powinien zdawać sobie sprawę przy wyciąganiu swoich wniosków. W wielu opracowaniach podejmuje się próby połączenia literacko-filologicznej i historyczno-krytycznej analizy z interpretacją teologiczną. Ale diachroniczny krytycyzm rozmawia raczej z umarłymi - starożytnymi skrybami i ich czytelnikami. W nie lepszej sytuacji znajdują się ujęcia synchroniczne, które wcale nie starają się mówić do dzisiejszych czytelników, lecz usiłują jedynie odkryć znaczenie adresowane do

34 Por. J.J. Collins, The Bible after Babel, s. 5n. 
pierwszych odbiorców finalnej postaci tekstu. A zatem, interpretacje historyczne i teologiczne nie uzupełniają się, gdyż teologiczna wykładnia proponowana w naukowej egzegezie odzwierciedla w istocie problemy pierwszych adresatów, i stąd ma charakter wykładni historycznej.

Powyższe założenia zmieniają status egzegety. Przywdziewa on szaty historyka, cieszącego się na uniwersytecie autonomią i niezależnością badań, którego osiągnięcia poddane są ocenie ze strony innych biblistów, podczas gdy oczekiwania i potrzeby wspólnoty wierzących nie stanowią dlań poważnego wyzwania badawczego. Następuje zmiana w moralności wiedzy biblijnej ${ }^{35}$. W swoich badaniach egzegeta czuje się odpowiedzialny wobec środowiska naukowego na wydziałach teologicznych, ustalających kryteria awansu zawodowego, które wpływają na kierunki i zakres jego badań (są to najczęściej tematy niszowe, jeszcze nieopracowane). Nie poczuwa się natomiast do podobnej odpowiedzialności w odniesieniu do wspólnoty kościelnej, nie podejmując zagadnień, które dla niej są istotne.

Podsumowując ten aspekt metodologii historyczno-krytycznej, należy podkreślić, że diachroniczny wymiar Biblii nie może być definiowany w hipotetycznie rekonstruowanej przeszłości, w odniesieniu do tego, co i jak było naprawdę, lecz znajduje swoje odzwierciedlenie na płaszczyźnie tekstualnej $\mathrm{w}$ ramach zapisu pamięci. Metoda historyczno-krytyczna często myli przeszłość z pamięcią. Nie mamy dostępu do przeszłości takiej, jaka ona była, lecz do pamięci, którą oczywiście musimy badać, krytycznie konfrontując ją nie tylko z pamięcią innych, lecz także analizując retoryczne sposoby jej przedstawiania. Po co pamiętamy? Żeby podzielić się z innymi tym, co przeżyliśmy, czego byliśmy świadkami i co z perspektywy czasu okazało się dla nas ważne. Wyróżnione tu niektóre zadania pamięci realizują się za pomocą sztuki opowiadania, która wykracza poza sztywne ramy metody i ściśle określonych procedur badawczych.

\section{Teoria narracji i jej hermeneutyczne implikacje ${ }^{36}$}

Zwrot narratywny w egzegezie spowodował powstanie metody analizy narracyjnej, która samą narrację sprowadza jednak do struktury tekstu. Stanowi ona kryterium klasyfikacji obszernego zbioru nie tylko dzieł literackiej fikcji, ale także historii czy mitu. Tymczasem współczesna hermeneutyka filozoficzna

35 Por. ibidem, s. 6.

36 Zarys problematyki związanej z teorią opowiadania i jej statusem hermeneutycznym zawiera: Z. Pawłowski, Opowiadanie, Bóg i początek, s. 158-230. 
widzi w narracji strukturę ludzkiego poznania i doświadczenia. Jej podstawową funkcją ,jest ujmowanie naszego własnego życia oraz rozwijających się w czasie procesów i zdarzeń zachodzących w świecie w całościowe struktury sen-

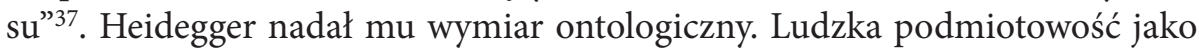
byt rozumiejący wykracza poza siebie, sytuując się w świecie. Ale to wykraczanie poza siebie w świat przyjmuje formę opowieści, jakie snujemy o sobie. $\mathrm{Z}$ tego względu postuluje się wprowadzenie hermeneutyki narracji do nauk podejmujących zagadnienia antropologiczne, gdyż metodologia przejęta z nauk przyrodniczych, poszukujących uniwersalnych praw, rządzących zjawiskami fizycznymi, nie jest zdolna opisać unikalności i wyjątkowości ludzkiej egzystencji, zwłaszcza jej podmiotowości i niepowtarzalności w wymiarze poszczególnych jednostek ${ }^{38}$. Urzeczywistnia się ona przede wszystkim w narracyjnie kształtowanej tożsamości osobowej. Dochodzi tu do głosu zdolność opowiadania własnej historii życia, w której znajduje zastosowanie rozumowanie narracyjne, wykorzystywane w zbiorach tradycyjnych opowieści, zgromadzonych i przechowywanych przez różne religie i kultury. Jego istota polega na śledzeniu fabuły, różniące się zasadniczo od myślenia dyskursywnego. Tryb dyskursywny posługuje się rozumowaniem analitycznym ${ }^{39}$, tryb narracyjny natomiast stanowi ujęcie syntetyczne, włączające wielorakie aspekty ludzkiej egzystencji w jednoczącą strukturę fabuły.

Jeśli opowieść jest sposobem tworzenia tożsamości ludzkiego podmiotu, rozwijającego się w czasie, to lektura opowieści stanowi równoległy proces rozszyfrowywania własnej tożsamości czytelnika albo wyrażając się językiem Prousta - odzyskiwaniem straconego czasu w zagubionej tożsamości ${ }^{40}$. Dlatego czytanie opowiadań biblijnych, choć wykorzystuje formalne elementy kompozycji narracji (metoda), zmierza do prawdy bycia. $\mathrm{Z}$ tego względu hermeneutyka opowieści nie pozwala sprowadzić teorii narracji do poziomu metody i zrównać ją z innymi metodami. Nie jest ona zwykłą metodą interpretacji tek-

37 K. Rosner, Narracja, tożsamość i czas, s. 12.

38 Por. D.E. Polkinghorne, Narrative Knowing and the Human Science, s. X.

39 Por. J. Zienkowski, J.-O. Östman, J. Verschueren (eds.), Discursive Pragmatics, s. $190-207$.

40 Por. w szczególności ostatni tom siedmiotomowej powieści Marcela Prousta W poszukiwaniu straconego czasu, zatytułowany Czas odnaleziony, s. 201, gdzie wyznaje: „Utwór pisarza nie jest niczym innym niż pewnego rodzaju instrumentem optycznym, który on podsuwa czytelnikowi, iżby ten potrafił dostrzec coś, czego by, nie mając owej książki, zapewne nie zobaczył w samym sobie. Rozpoznanie przez czytelnika treści książki w samym sobie, dowodzi, że książka jest prawdziwa i vice versa..." Zob. wnikliwe rozważania hermeneutyczne dotyczące tej powieści autorstwa P. Ricoeura, zawarte w: Czas i opowieść, t. II, s. $208-240$. 
stów, lecz hermeneutyką ludzkiego bytu w mocnym ontologicznym sensie. Nie można poprzestać na analizie formalnych aspektów narracyjności, zadowalając się klasyfikacją różnorodnych technik kompozycji i zastosowanych w niej środków retorycznych. Każdy tekst narracyjny ma formę skończonego dzieła, które chce przekazać jakieś zrozumiałe orędzie. Tym, co je spaja, wyznaczając ściśle określone granice, jest fabuła, którą jednak można pojmować dwojako. Na modłę strukturalizmu, można widzieć w niej achroniczne schematy, tworzące programy narracyjne, w których czas nie odkrywa żadnej roli, i w związku z tym wszelkie przekształcenia czasowe wewnątrz fabuły pozostają niezauważalne i są pominięte. Fabułę można jednak także rozumieć w sensie konfiguracji czasowej w duchu Poetyki Arystotelesa, Wyznań Augustyna, czy współczesnych powieści, w których bohaterem jest czas ${ }^{41}$, a w której heterogeniczne wielkości, takie jak usytuowanie przestrzenne, postaci, zdarzenia i działania, zostają zespolone w jedną czasową strukturę konfiguracyjną. Ta ostatnia wydaje się bardziej odpowiadać naturze biblijnych opowiadań. Poszukując spójności fabuły (odwzorowującą jedność własnego życia), czytelnik za pomocą rozumowania narracyjnego stara się odpowiedzieć na pytanie, dlaczego zdarzenia, zachowania bohaterów i okoliczności mają taki a nie inny przebieg, i co je wszystkie spaja ze sobą. Napotyka przy tym sprawiające mu trudność pęknięcia, przeskoki i niedopowiedzenia. Próbując je rozwiązać, wkracza w fazę wyjaśnienia, w której obok domysłów, wynikających z analizy fabuły (zastosowanych w niej technik i środków retorycznych), musi także z konieczności uwzględnić historyczny dystans dzielący go od tekstu i zbadać go za pomocą procedur metody historyczno-krytycznej. Ma ona jednak charakter wyłącznie pomocniczy. Jej celem jest ustrzec czytelnika przed wszelkimi anachronizmami w interpretacji, a więc przypisywaniem tekstowi tych aspektów znaczeń, które są mu obce, a które mogą pochodzić z aktualnej sytuacji czytelnika. Trzeba jednocześnie uważać, żeby nie wpaść w pokusę nadmiaru wiedzy historycznej, mogącej całkowicie przesłonić główne przesłania tekstu.

Z perspektywy tak zdefiniowanej hermeneutyki narracji, sztuka tworzenia opowiadań, staje się według Paula Ricoeura, sztuką wymiany doświadczeń. Przez doświadczenie rozumie on nie naukową obserwację, lecz korzystanie z mądrości praktycznej. Zawiera ona w sobie zawsze jakieś sądy, wartościowania, hierarchie zadań i celów. Jedną z podstawowych funkcji wymiany doświadczeń, urzeczywistniającej się w opowieści, jest uznać pewne działania

41 Narracja opisuje na najbardziej podstawowym poziomie zmiany $w$ czasie i pod tym względem ma charakter uniwersalny, przekraczając granice odrębności kulturowej. Oczywiście poszczególne opowiadania różnią się od siebie, ale w wymiarze przeobrażeń konfiguracyjnych. Więcej na ten temat, zob. Z. Pawłowski, Opowiadanie, Bóg i początek, s. 165-189. 
i zachowania za właściwe lub je potępić, a ich sprawców pochwalić lub zganić. Lektura opowieści służy więc także odkryciom dokonywanym w krainie dobra i zła. Właśnie dzięki tym ćwiczeniom w wartościowaniu opowiadanie może ostatecznie spełniać swą funkcję objawiającą, jak również przyczyniać się do przemiany czytelnika w sferze jego uczuć i działań. Tym samym opowieść narratywizuje dążenie do prawdziwego życia, nadając postaciom w niej występującym rozpoznawalne rysy lubianych i szanowanych bohaterów ${ }^{42}$. W portretach biblijnych postaci pomija się z reguły elementy zewnętrznego wyglądu i cechy charakteru. Przedstawia się je raczej wewnątrz dramatycznie rozwijającej się fabuły, przeprowadzając przez rozliczne przeobrażenia, wyartykułowane za pomocą jej złożonego układu konfiguracyjnego. Wyłaniają się one nie z hipotetycznie rekonstruowanego Sitz im Leben, ale z Sitz im Wort, jakim jest struktura narracyjna tekstu.

Mając to na uwadze, Dokument Papieskiej Komisji Biblijnej, dotyczący interpretacji, łączy problematykę aktualizacji z potrzebą podwójnego opowiadania: opowiadania historii zbawienia, przedstawionej w Piśmie oraz opowiadania w świetle historii zbawienia ${ }^{43}$. Jeśli egzegeza narracyjna objawia niezwykłą elokwencję w pierwszej kwestii, to notorycznie pomija drugą w milczącym założeniu, iż nie jest ona niezbędnym warunkiem dla zrozumienia tekstu biblijnego. Wręcz przeciwnie, ktoś, kto nie zacznie opowiadać własnej historii życia, śledzić ukrytych w niej wątków fabularnych i tropić struktury narracyjne, nadające im jedność, nigdy może nie zrozumieć biblijnych opowiadań, a zwłaszcza losów występujących w nich postaci.

Właśnie struktura narracji, w sensie czasowej konfiguracji fabuły, stanowi podstawę przyswojenia, gdyż układ zdarzeń w swoich rozlicznych przekształceniach jest tak samo odbierany i przeżywany przez wszystkich ludzi, niezależnie od ich usytuowania w historii. Według Ricoeura przyswojenie odbywa się w trzech wymiarach, w których opowiadanie spełnia funkcję zapośredniczenia między człowiekiem a światem (w wymiarze referencji), między człowiekiem a człowiekiem (na płaszczyźnie komunikacji) oraz między człowiekiem a samym sobą (w aspekcie samo-rozumienia). Te trzy rodzaje zapośredniczenia wyznaczają potencjalne kierunki aktualizacji, choć nie wszystkie teksty dadzą się aktualizować jednocześnie w tych trzech wymiarach ${ }^{44}$.

42 Por. P. Ricoeur, O sobie samym jako innym, s. 271-274. 


\section{Zakończenie}

Metoda historyczno-krytyczna, dzięki której biblistyka przerodziła się w ogromny przemysł, dostarczający ciągle nowych informacji historycznych, w niewielkim stopniu stanowi narzędzie dotarcia do prawdy tekstów biblijnych ${ }^{45}$. Owszem, jej niezbywalną zasługą jest dokonanie zmiany w rozumieniu Pisma, które odtąd nie może być traktowane jako zbiór oczywistych twierdzeń, uzasadniających doktrynę chrześcijańską. Odsłaniając jego historyczny charakter, uświadamia współczesnym czytelnikom, że żaden jego fragment nie jest zrozumiały sam z siebie, lecz w swej inności, spowodowanej dystansem historycznym, wymaga wysiłku interpretacji. Pismo wyzwolone z podporządkowania doktrynie, mogło zacząć być czytane jako Pismo samo w sobie, tak jak było i dalej jest czytane w tradycji żydowskiej.

Nadmiernie rozbudowanej metodologii, poszukującej coraz bardziej wymyślnych metod analizowania tekstów, należałoby przeciwstawić ascetyczność aktu interpretacji, odwołującego się do zdolności rozumowania narracyjnego, w którym ludzka osoba, doświadczając czasowego wymiaru swej własnej egzystencji, potrafi przyswoić siebie przedłożoną jej opowieść i wykorzystać ją do przedstawienia swojego życia w formie opowiadanej historii, stając się jednocześnie jej narratorem i autorem w wymiarze odzyskiwanej tożsamości. Rozumowanie narracyjne powinno uwzględnić wiele elementów i aspektów, zarówno odniesienia do zdarzeń historycznych jak i postaci w nich uwikłanych, ale także ich działania, intencje, motywy i wypowiedzi, wreszcie, struktury czasu i wymiary przestrzenne. Wszystkie te elementy łączą się w rozwijającą się w czasie i otwartą na nowe scenariusze fabułę. To, co Gadamer mówi o rozumieniu przyjmującym postać 'gry językowej', w istocie odnosi się przede wszystkim do rozumowania narracyjnego, w którym kluczową rolę pełni proces rozwikłania fabuły opowieści. W nim czytelnik staje się jednym z jej uczestników.

Współczesna biblistyka, z punktu widzenia hermeneutyki opowieści, uwzględniającej perspektywę dzisiejszego czytelnika, mało troszczy się o jego problemy i oczekiwania. Grono odbiorców ogranicza się do stosunkowo nielicznej grupy uczonych, którzy tworzą dla siebie samych, odwołując się do wyników badań swoich kolegów, co jest nieodzowne w procesie wspinania się po szczeblach kariery naukowej. Jeśli interpretację Biblii traktować jako kluczową dla tożsamości chrześcijańskiej, co postulują zarówno dokumenty Soboru Watykańskiego II, jak i wypowiedzi ostatnich papieży, to badania biblijne w niewielkim stopniu wypełniają powierzoną im misję. Mnożą się nowe pro-

45 Por. L.A. Schökel, A Manual of Hermeneutics, s. 148-161. 
jekty i kierunki badań, choć zainteresowanie i rozumienie Biblii w kontekście współczesnych problemów jest coraz mniejsze, a paradygmat naukowy, z jego ambiwalentnymi osiągnięciami, przejmuje kolejne sfery życia jednostek i społeczeństw. Brakuje również szczerej dyskusji nad rzeczywistą kondycją dzisiejszej biblistyki, jej celami i misją w kościele, nad tożsamością egzegety i jego zadaniami nie tylko na uniwersytecie, ale także nad jego rolą we wspólnotach kościelnych. Dlatego obydwie muszą znaleźć wyznaczone sobie miejsce w szerszym i bardziej pojemnym modelu hermeneutycznym ${ }^{46}$. Musi on na nowo połączyć oddzielone od siebie przestrzenie aktywności interpretacyjnej - uniwersytet i kościół w taki sposób, aby Pismo znowu stało się źródłem inspiracji i impulsem transformacji wszystkich jego czytelników ${ }^{47}$.

\section{Bibliografia}

Alonso Schökel L., A Manual of Hermeneutics, Sheffield 1998.

Collins J., The Bible after Babel. Historical Criticism in a Postmodern Age, Grand Rapids, Michigan, Cambridge 2005.

Forster, M., Friedrich Daniel Ernst Schleiermacher, The Stanford Encyclopedia of Philosophy (Fall 2017 Edition), Edward N. Zalta (ed.), URL $=<$ https://plato.stanford. edu/archives/fall2017/entries/schleiermacher/> (dostęp: 02.05.2018).

Gitay Y., The Prophetic Criticism, JSOT 96 (2001), s. 101-127.

Harrison P., The Bible, Protestantism, and the Rise of Natural Science, Cambridge 1998. Iser W., The Range of Interpretation, New York 2000.

Kowalski M., Retoryka i socjoretoryka w lekturze tekstów Nowego Testamentu. Cz. 2: Socjoretoryka - projekt holistycznej lektury tekstu, The Biblical Annals 7/1 (2017), s. $107-147$.

Moberly W., Jonah, God's Objectionable Mercy, and the Way of Wisdom, w: Ford D.F., Stanton G. (eds.), Reading Text, Seeking Wisdom, London 2003, s. 154-168.

Pawłowski Z., Opowiadanie, Bóg i początek. Teologia narracyjna Rdz 1-3, Warszawa 2013.

Pawłowski Z., Wiara i metoda w interpretacji Biblii. Przekaz wiary czy przekaz wiedzy: biblijna interpretacja na rozdrożu, Biblica et Patristica Thoruniensia 7 (2014) 1, s. 9-28. DOI: http://dx.doi.org/10.12775/BPTh.2014.001 (dostęp: 02.05.2018).

Polkinghorne D. E., Narrative Knowing and the Human Science, State University of New York Press, New York 1988.

Proust M., W poszukiwaniu straconego czasu, t. 7: Czas odnaleziony, Warszawa 2001.

Ricoeur P., Czas i opowieść, t. II, Kraków 2008.

Ricoeur P., Egzystencja i hermeneutyka. Rozprawy o metodzie, Warszawa 1985.

Por. Y. Gitay, The Prophetic Criticism, s. 127 (101-127).

47

Por. W. Moberly, Jonah, God's Objectionable Mercy, and the Way of Wisdom, s. 154n. 
Ricoeur P., O sobie samym jako innym, Warszawa 2003.

Ricoeur P., A Ricoeur Reader: Reflection and Imagination, M. Valdés (ed.), New York-London 1991.

Rosner K., Narracja, tożsamość i czas, Kraków 2003.

Rubinkiewicz R. (przekł. i red.), Interpretacja Biblii w Kościele. Dokument Papieskiej Komisji Biblijnej z komentarzem biblistów polskich, Warszawa 1999.

Sakenfeld K.D., Whose Text Is It?, Journal of Biblical Literature 127/1 (2008), s. 5-18.

Spark K., The Prophetic Speeches in Chronicles. Speculation, Revelations, and Ancient Historiography, Bulletine for Biblical Research 9 (1999), s. 233-245.

Whybray R.N., The Making of the Pentateuch. A Methodological Study, Journal for the Study of the Old Testament, Suppl. 53, Sheffield 1987.

Zienkowski J., Östman J.-O., Verschueren J. (eds.), Discursive Pragmatics, Amsterdam, Philadephia 2011, s. 190-207. 